Article

\title{
The Role of Mediated Oxidation on the Electro-irradiated Treatment of Amoxicillin and Ampicillin Polluted Wastewater
}

\author{
Fernando L. Silva ${ }^{1}$, Cristina Sáez ${ }^{2, *}$, Marcos R.V. Lanza ${ }^{1}$, Pablo Cañizares ${ }^{2}$ and \\ Manuel A. Rodrigo ${ }^{2}$ \\ 1 Institute of Chemistry of São Carlos, University of São Paulo, P.O. Box 780, 13560-970 São Carlos-SP, Brazil; \\ fernandolindosilva@gmail.com (F.L.S.); marcoslanza@iqsc.usp.br (M.R.V.L.) \\ 2 Chemical Engineering Department, University of Castilla-La Mancha, Edificio Enrique Costa Novella. \\ Campus Universitario s/n, 13005 Ciudad Real, Spain; pablo.canizares@uclm.es (P.C.); \\ manuel.rodrigo@uclm.es (M.A.R) \\ * Correspondence: Cristina.Saez@uclm.es; Tel.: +34-902-204-100
}

Received: 2 November 2018; Accepted: 18 December 2018; Published: 24 December 2018

check for updates

\begin{abstract}
In this work, the electrolysis, photoelectrolysis and sonoelectrolysis with diamond electrodes of amoxicillin (AMX) and ampicillin (AMP) solutions were studied in the context of the search for technologies capable of removing antibiotics from liquid wastes. Single-irradiation processes (sonolysis and photolysis) were also evaluated for comparison. Results showed that AMX and AMP are completely degraded and mineralized by electrolysis in both chloride and sulfate media, although the efficiency is higher in the presence of chloride. The effect of the current density on mineralization efficiency is not relevant and this may be related to the role of mediated oxidation. Irradiation by ultraviolet light or ultrasound (US) waves does not produce a synergistic effect on the mineralization of AMX and AMP solutions. This indicates that the massive formation of radicals during the combined processes can favor their recombination to form stable and less reactive species.
\end{abstract}

Keywords: Anodic oxidation; diamond electrodes; UV irradiation; ultrasounds; amoxicillin; ampicillin

\section{Introduction}

The development of modern society is providing continuous improvements to quality of life, increasing food production through the use of agrochemicals and improving health with the use of biologically active substances for the control of diseases. These chemicals may pose some environmental risks and as a result of this, they have recently been the focus of a good deal of research globally [1,2]. Regarding medicines, antibiotics are worth highlighting because of their extensive consumption and extremely high potential environmental risks [3-8], reflected by the occurrence of super-bacteria, which are becoming a very serious health problem. Often, these chemicals are not efficiently removed in conventional wastewater treatment facilities, and consequently they are discharged into the environment where they are accumulated [9], altering the biological cycle of many types of organisms.

The use of beta-lactam antibiotics, such as amoxicillin (AMX) and ampicillin (AMP), represented an important contribution to medical science from the end of World War II. These medicines are still widely used because of their high efficiency, low cost and few side effects in humans. While ampicillin is more suitable for the treatment of respiratory tract infections, amoxicillin has several applications in infections of the skin and soft tissues, odontogenic infection, lower respiratory tract infection or 
urinary tract infection and otitis. Studies related to these molecules have developed because they have been detected in different sites. For example, monitoring performed at sewage treatment stations located in different regions of Italy showed concentrations of amoxicillin in the final effluent in the range of $1.8 \mathrm{ng} \mathrm{L}^{-1}$ to $120 \mathrm{\eta g} \mathrm{L}^{-1}$.

The removal of antibiotics from water is neither easy nor efficient with conventional technologies. For this reason, many advanced oxidation processes (AOPs) have been suggested and proven over the last years [10]. Among them, photochemical oxidation, ozonation, photolysis with $\mathrm{H}_{2} \mathrm{O}_{2}$ and $\mathrm{O}_{3}$, photocatalysis, and Fenton processes are worthy of mention. The main characteristic of these processes is the generation of very reactive and oxidizing radicals, such as hydroxyl radicals. Presently, electrolysis is one of the most interesting AOPs, and has been shown to be a very capable technology for the elimination of organic pollutants [11-16], including antibiotics. The efficiency of this technology depends not only on the operating conditions of the system but also on the material used as an anode. In the case of using conductive diamond electrodes, the massive generation of hydroxyl radicals is reported. This is a very powerful oxidant $\left(\mathrm{E}^{0}: 2.80 \mathrm{~V}\right.$ vs SHE) that can not only react with organics but also promotes the generation of other oxidants, such as peroxophosphates, peroxosulfates, ozone, and hydrogen peroxide [17-19].

The electrolysis of antibiotics has been studied previously with successful results, which suggests that electrolysis is a technology worth evaluating [20-27]. However, these molecules are very complex and there is a need for further investigations in order to determine the conditions in which these processes can be optimized. Electrolysis is very efficient when the concentration of organics is in the range of $10^{3}-10^{4} \mathrm{ppm}$, and the concentrations of antibiotics in urine are much lower; thus, improved knowledge about the mechanisms and possible synergies with other technologies (such as photoor sono-processes) could help the development of future processes which are capable of solving the problem efficiently [28-31].

In this context, the goal of the present study is to evaluate the applicability of electrochemical oxidation with diamond anodes to remove waste consisting of mixtures of amoxicillin and ampicillin, clarifying the effects of the current density and supporting electrolyte on the performance of the process. In order to improve this performance, irradiation by UV light and ultrasounds during electrolysis is also evaluated, with the final aim of explaining the way in which the process mediated by electrogenerated oxidants affects amoxicillin/ampicillin oxidation. As seen in Table 1, the chemical structure of both molecules is quite similar. Hence, initially it may be expected that both molecules will be oxidized at similar rates and as a result of similar mechanisms. Similarities and differences found are expected to clarify mechanisms.

Table 1. Chemical structure of amoxicillin and ampicillin.

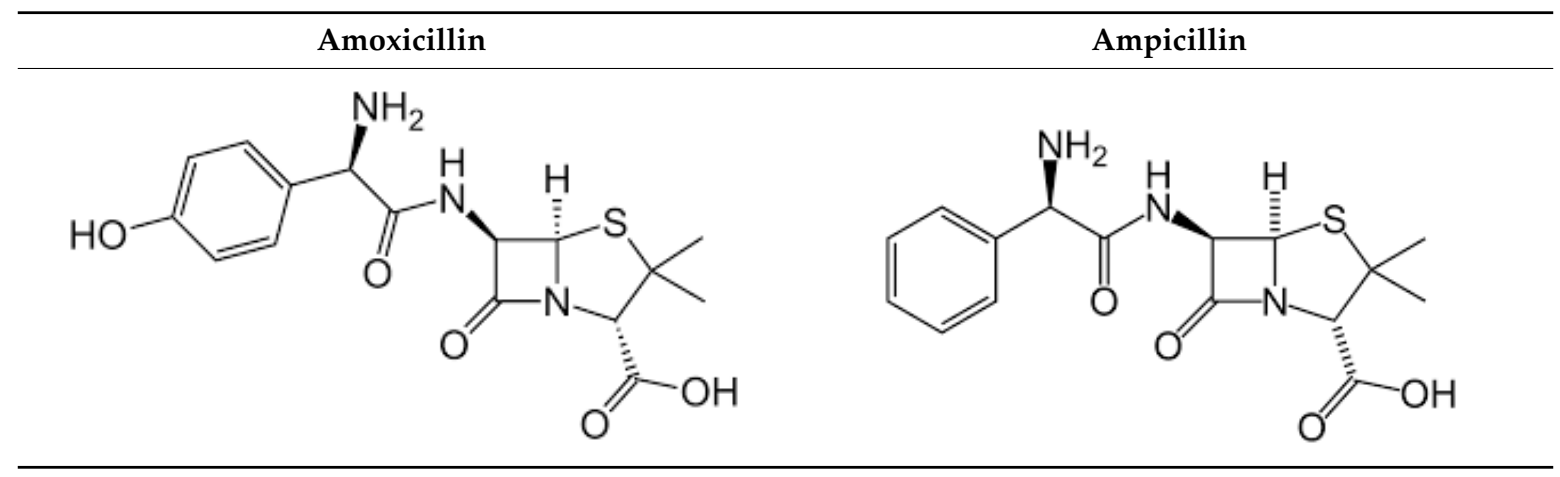

\section{Results and Discussion}

Figure 1 shows the removal of antibiotics and total organic carbon (TOC), as a function of the current charge passed during the electrolysis of amoxicillin (AMX) and ampicillin (AMP) solutions, carried out in sulphate media at three current densities $\left(15,30\right.$ and $\left.60 \mathrm{~mA} \mathrm{~cm}^{-2}\right)$. As can be observed 
in Figure 1a, both AMX and AMP are completely oxidized during the electrolyses, and their decay trends lie over almost the same curve. Thus, they disappeared completely after passing similar electric charges. This similar trend can be explained in terms of their similar chemical structure. Regarding the effect of current density, the electric charges required to attain a given percentage removal depends on the following parameter: 8, 6, and 5.5. Ah dm${ }^{-3}$ at 15, 30 and $60 \mathrm{~mA} \mathrm{~cm}{ }^{-2}$, respectively. Moreover, as it is known, the slope of this representation (d[concentration] / $d Q$ ) refers to the oxidation efficiency. There is an evident improvement of the degradation when the current density increases from 15 to $30 \mathrm{~mA} \mathrm{~cm}^{-2}$. From 30 to $60 \mathrm{~mA} \mathrm{~cm}^{-2}$, this improvement is less evident and it is only observed during the initial stages of the electrolysis. Thus, the higher the current density, the more efficient the partial degradation of the raw material. It is important to bear in mind that the antibiotics were measured by high performance liquid chromatography (HPLC), and any change in functional group causes the transformation of the raw molecule into an intermediate; hence its disappearance in the HPLC chromatogram. However, this trend observed in the raw antibiotic molecules is not reflected for TOC removal (Figure 1b). In fact, the electric charge required to attain the complete mineralization of the waste increases with current density: 12,14 , and $24 \mathrm{Ah} \mathrm{dm}^{-3}$ in the electrolyses carried out at 15, 30 and $60 \mathrm{~mA} \mathrm{~cm}^{-2}$, respectively. Taking into account the resultant cell voltage in each case $(4.8,5.7$ and $6.8 \mathrm{~V}$, respectively), these differences are even more relevant in terms of energy consumption. Additionally, the electric current charges required for mineralization are higher than those passed to attain the complete depletion of the initial compound. This observation confirms that the oxidation of AMP and AMX occurs gradually and organic intermediates should be formed (see inset of Figure 1b). Finally, these intermediates are further oxidized to carbon dioxide, being more efficiently degraded at lower current densities, perhaps because of the major influence of the processes occurring in close proximity to the anode surface under those conditions.
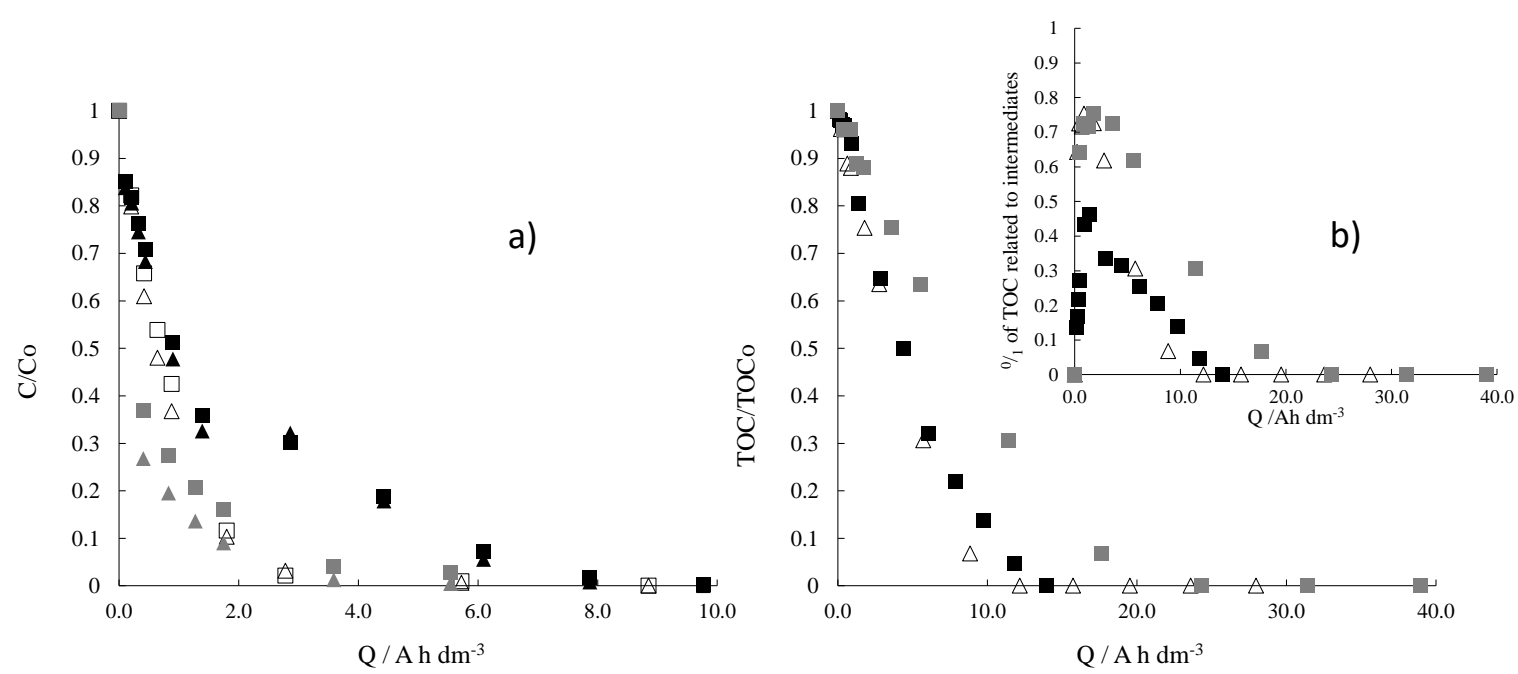

Figure 1. Oxidation trends of the antibiotics amoxicillin $(\operatorname{AMX})(\boldsymbol{\Delta}, \Delta, \Delta)$ and ampicillin $(\mathrm{AMP})$ $\square, \square)(\mathbf{a})$ and of total organic carbon (TOC) (b) with the electric charge passed during the electrolysis carried out in sulphate media $\left(3 \mathrm{~g} \mathrm{~L}^{-1}\right.$ of $\left.\mathrm{Na}_{2} \mathrm{SO}_{4}\right)$ at three current densities: 15 (black symbols), 30 (white symbols), and 60 (grey symbols) $\mathrm{mA} \mathrm{cm}^{-2}$. Initial concentration was $100 \mathrm{mg} \mathrm{L}^{-1}$ of AMX and $100 \mathrm{mg} \mathrm{L}^{-1}$ of AMP.

At this point, it is important to take into consideration that in the electrolysis with conductive diamond electrodes, both direct and mediated oxidation (thanks to oxidants electrogenerated in the system) can contribute to the overall degradation process [32]. In the tests shown in Figure 1, sulphate was used as a supporting electrolyte, and it is well known that electrolysis can lead to the formation of peroxo-sulphates (Equation (1)) [17,33]. Additionally, this type of electrode also promotes the production of free hydroxyl radicals (Equation (2)) that recombine among them or react with 
oxygen to form $\mathrm{O}_{3}$ (Equation (3)) and $\mathrm{H}_{2} \mathrm{O}_{2}$ (Equation (4)). These oxidants can also contribute to the oxidation process.

$$
\begin{gathered}
2 \mathrm{SO}_{4}{ }^{2-} \rightarrow \mathrm{S}_{2} \mathrm{O}_{8}{ }^{2-}+2 \mathrm{e}^{-} \\
\mathrm{H}_{2} \mathrm{O} \rightarrow(\bullet \mathrm{OH})+\mathrm{H}^{+}+\mathrm{e}^{-} \\
\mathrm{O}_{2}+2(\bullet \mathrm{OH}) \rightarrow \mathrm{O}_{3}+\mathrm{H}_{2} \mathrm{O} \\
2(\bullet \mathrm{OH}) \rightarrow \mathrm{H}_{2} \mathrm{O}_{2}
\end{gathered}
$$

The formation of these species is promoted at high current density [26,34,35], but it is not always reflected by a more efficient degradation. In fact, in light of the results obtained in this study, the transformation of AMP and AMX is favored at high current densities, but not their full mineralization. This observation implies that although more oxidants are generated, the mineralization of intermediates becomes less effective under these conditions. This can be explained by the low reactivity of the intermediates with the oxidants, which made the direct oxidation mechanisms the most important in their degradation. This may explain the typical behaviour of diffusion-controlled systems, in which a mass transfer from the bulk to the electrode surface controls the rate of oxidation processes in spite of the presence of large amounts of oxidants in the reaction system. Thus, if the electrogenerated oxidants are not able to oxidize the reaction intermediates, the efficiency of the overall process decreases.

To determine the kinetics of the mineralization process, in Figure 2 the TOC removals are plotted on a semi-log scale. As can be observed, it is possible to distinguish two zones in which the slope of the trend changes, regardless of the current density. In each zone, the data show linear trends, indicating that electrolysis fits the kinetic of the pseudo-first order.

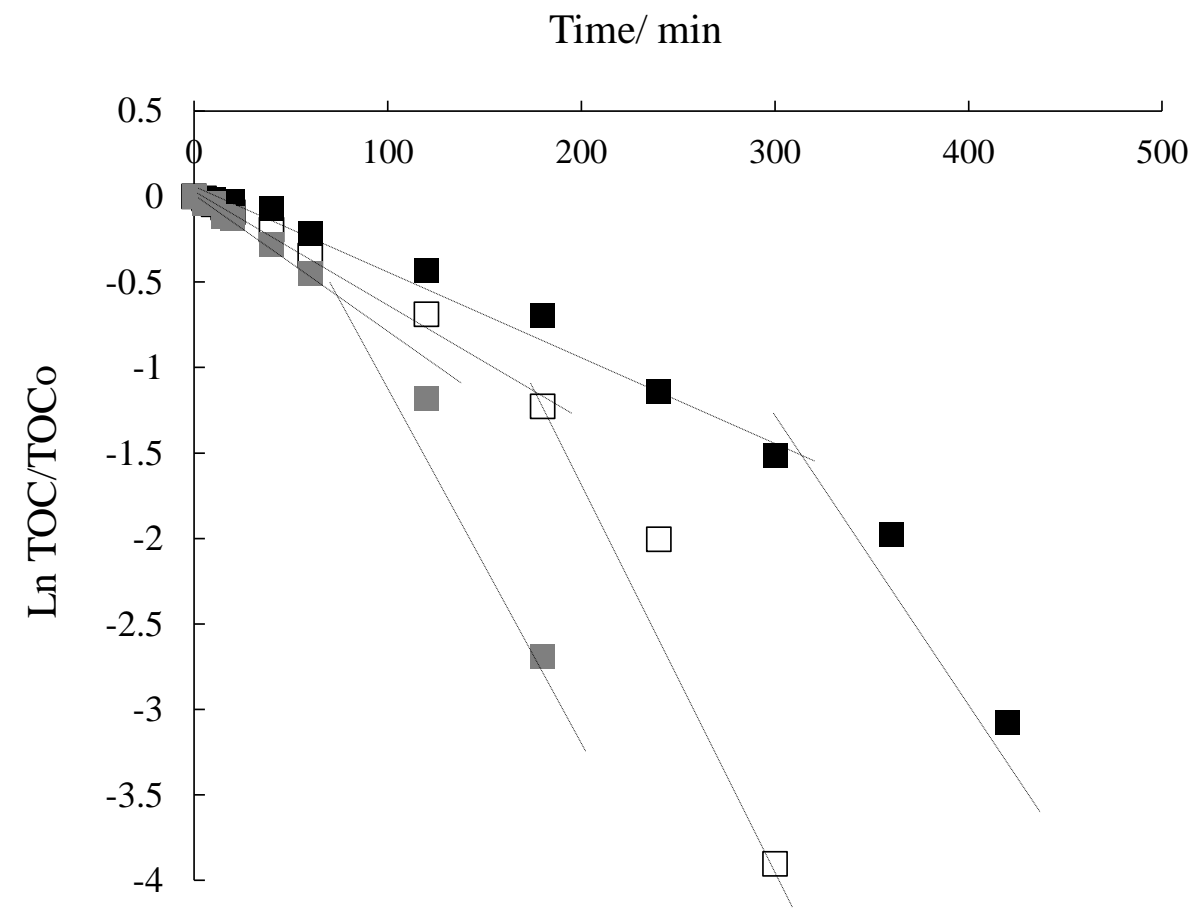

Figure 2. TOC removal in semi-log scale during electrolysis of AMX and AMP solutions carried out in sulphate media $\left(3 \mathrm{~g} \mathrm{~L}^{-1}\right.$ of $\left.\mathrm{Na}_{2} \mathrm{SO}_{4}\right)$ at three current densities: $15(\mathbf{\square}), 30(\square)$ and $60(\square) \mathrm{mA} \mathrm{cm}^{-2}$. Initial concentration was $100 \mathrm{mg} \mathrm{L}^{-1}$ of AMX and $100 \mathrm{mg} \mathrm{L}^{-1}$ of AMP.

In the first zone, the kinetic is slower and the current density shows a higher influence $\left(\mathrm{k}_{1}=\right.$ $0.0062,0.0103$ and $0.0115 \mathrm{~min}^{-1}$ at 15,30 and $60 \mathrm{~mA} \mathrm{~cm}^{-2}$, respectively). In this zone, AMX and AMP are the main organics present in the solution and, as shown in Figure 1, their attack is favored 
with the increase in electron current. These electrons are used to transform the initial pollutants to intermediates by attacking functional groups or double bonds (partial oxidation). Thus, in terms of mineralization, the electric charge supplied is not efficiently used because it is not used to form carbon dioxide but only intermediates.

In the second zone, the mineralization rate increases and the electrons supplied seem to be efficiently used. Before this, a transition region can be observed, in which the change of trends starts to become evident. Here, around $80-90 \%$ of the antibiotics have been transformed and around $30 \%$ of TOC has been mineralized; therefore, it may be assumed that small amounts of the raw pollutants coexist with both aromatic and aliphatic intermediates. This behaviour has been observed in previous works [32] and can be explained by the presence of short-chain carboxylic acids during the final stages of the degradation process, whose oxidation may be favored by the cocktail of oxidants formed and leads almost directly to carbon dioxide. Consequently, the slope increases significantly until 0.2197 , 0.2084 and $0.2236 \mathrm{~min}^{-1}$. Additionally, it is observed that the kinetic constants are similar at the three current densities, confirming the role of the mass transfer limitations, particularly in low-concentration solutions (TOC concentrations below $25 \mathrm{mg} \mathrm{L}^{-1}$ )

At this point, in the literature it has been reported that electrogenerated oxidants should be activated to promote mediated oxidation efficiently [36-43]. It is well known that the photo-activation of stable oxidants in the bulk can occur when the electrolytic system is irradiated with UV light. Commonly, the radical oxidizing agents formed (Equations (5)-(7)) react faster than the corresponding oxidant-anions, and this enhances the degradation process.

$$
\begin{gathered}
\mathrm{S}_{2} \mathrm{O}_{8}{ }^{2-}+U V \text { light } \rightarrow 2\left(\mathrm{SO}_{4}{ }^{-}\right) \\
\mathrm{H}_{2} \mathrm{O}_{2}+U V \text { light } \rightarrow 2{ }^{\bullet} \mathrm{OH} \\
\mathrm{H}_{2} \mathrm{O}+\mathrm{O}_{3}+U V \text { light } \rightarrow 2{ }^{\bullet} \mathrm{OH}+\mathrm{O}_{2}
\end{gathered}
$$

In the search for better efficiencies, AMP and AMX solutions undergoing the electrochemical process at $30 \mathrm{~mA} \mathrm{~cm}{ }^{-2}$ were irradiated with $254 \mathrm{~nm}$ of UV light. Figure 3 shows the degradation trends of AMX and AMP during the combined process of photoelectrolysis in sulphate media. For comparison purposes, the role of the supporting electrolyte was also evaluated. It is well known that hypochlorite can be formed during electrolysis with conductive diamond electrodes in chlorine media (Equation (8)) and that, under UV light irradiation, hypochlorite is also decomposed into chlorine radicals (Equation (9)). Therefore, attending to the main mediator formed in each case (sulphate or chloride media), differences are expected. Additionally, to evaluate the existence of possible synergisms in the combined process, the results are compared with those obtained in the single processes of photolysis (without applying current) and electrolysis (without irradiating UV light).

$$
\begin{aligned}
& \mathrm{Cl}^{-}+\mathrm{H}_{2} \mathrm{O} \rightarrow \mathrm{HClO}+\mathrm{H}^{+}+2 \mathrm{e}^{-} \\
& \mathrm{ClO}^{-}+U \text { V light } \rightarrow \mathrm{Cl}^{\bullet}+\mathrm{O}^{-\bullet}
\end{aligned}
$$



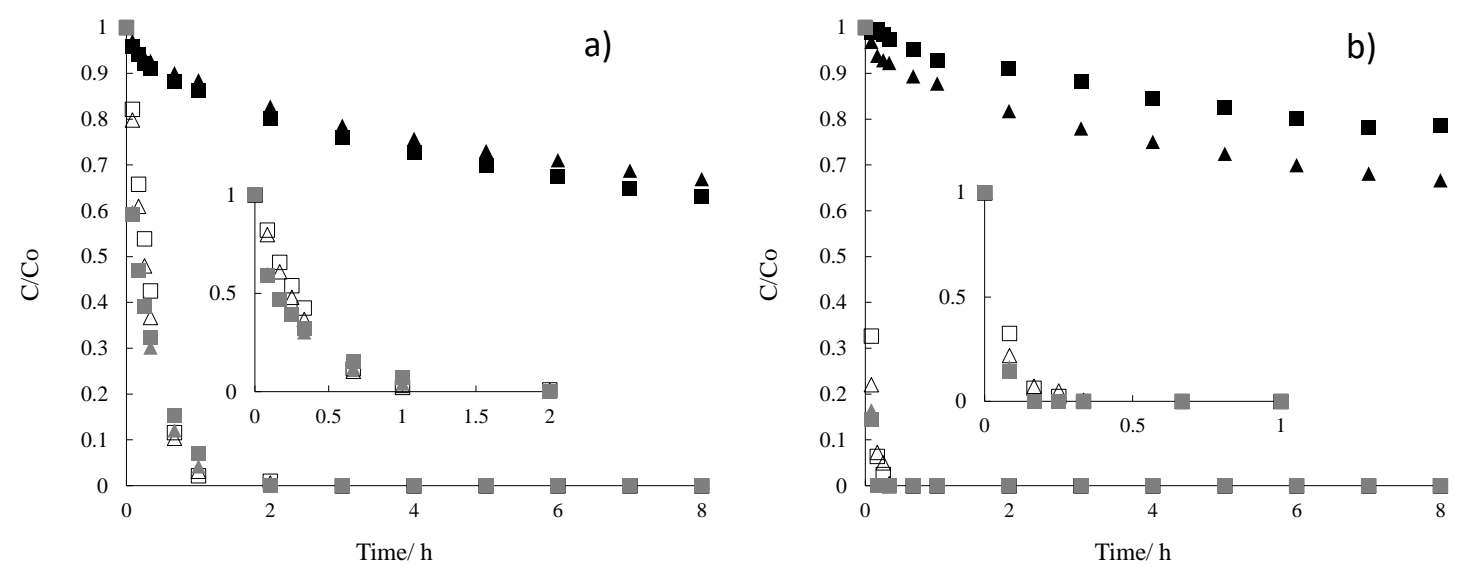

Figure 3. Degradation trends of AMX (triangles) and AMP (squares) during the electrolysis $(\Delta, \square$ ), photolysis $(\boldsymbol{\Lambda}, \mathbf{\square})$ and photoelectrolysis $(\boldsymbol{\Lambda}, \mathbf{\square})$ tests in sulphate media (a) and chlorine $(\mathbf{b})$. Initial concentration: $100 \mathrm{mg} \mathrm{L}^{-1}$ of AMX and $100 \mathrm{mg} \mathrm{L}^{-1}$ of AMP. Electrolyte concentrations: $3 \mathrm{~g} \mathrm{~L}^{-1}$ of $\mathrm{Na}_{2} \mathrm{SO}_{4}$ or $3.7 \mathrm{~g} \mathrm{~L}^{-1}$ of $\mathrm{NaCl}$. Current density: $30 \mathrm{~mA} \mathrm{~cm}^{-2}$ : UV light: $254 \mathrm{~nm}$.

As can be observed, the partial oxidation of AMX and AMP depends on the technology used. As expected [26,34,35], photolysis is not able to completely remove the antibiotics, and around $70 \%$ of AMX and AMP remains unaltered in the solutions after $8 \mathrm{~h}$ of treatment. Moreover, in sulphate media, the removal trends of both compounds are almost overlapping, but they differ significantly in chlorine media, in which the degradation of AMP is slower. As the difference between both antibiotic is just one hydroxyl group in the aromatic ring, it means that the oxidation obtained by photolysis is focused on this group primarily and that mediators formed in chloride medium are not as effective in the oxidation of other groups. On the contrary, less than $1 \mathrm{~h}$ of treatment is required to attain the complete depletion of AMP and AMX in the electrolysis tests. In fact, the partial oxidation of AMX and AMP is even faster in chlorine media, and after $0.25 \mathrm{~h}$ of electrolysis at $30 \mathrm{~mA}$ $\mathrm{cm}^{-2}$, both antibiotics have completely disappeared from the reaction system. According to the literature $[26,34,35]$, in chlorine media, the rapid chlorination of aromatic compounds occurs by the attack of electrogenerated $\mathrm{Cl}_{2} / \mathrm{HClO} / \mathrm{ClO}^{-}$, although in many cases it is not accompanied by a rapid TOC removal.

Another important observation is that, in both evaluated scenarios, the contribution of the irradiation does not seem to be as relevant as expected: a slight improvement is observed in the first stages of the process (see insets of Figure 3), but this changes when around $70 \%$ of the raw organic has been transformed. It may be related to the competitive oxidation of reaction intermediates by activated oxidants.

To evaluate the effect of the irradiation on the mineralization, Figure 4 shows TOC removal in a semi-log scale of the electrolysis, photoelectrolysis and photolysis tests in both sulphate and chlorine media. As can be seen, the slight depletion of AMP and AMX shown in Figure 3 during the photolysis tests is not reflected by the TOC values, indicating that UV light irradiation at $254 \mathrm{~nm}$ is not able to convert these organics directly to carbon dioxide, and only a soft transformation of the molecule occurs. On the other hand, the effect of combining UV light irradiation with electrolysis does not seem to be particularly remarkable as regards mineralization and the data of electrolysis and photoelectrolysis lie over the same line, regardless of the supporting electrolyte used. 

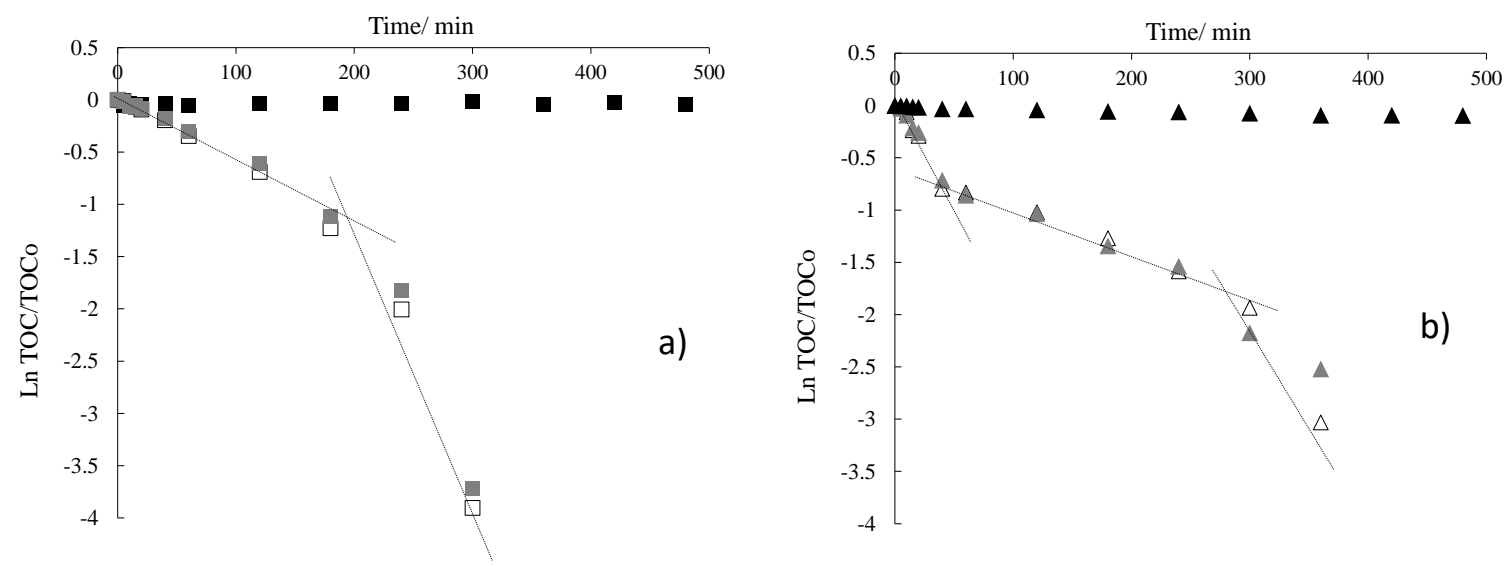

Figure 4. TOC removal in semi-log scale during the electrolysis (white symbols), photoelectrolysis (grey symbols) and photolysis (black symbols) of AMX and AMP solutions carried out in sulphate media (a) and chlorine media (b). Initial concentrations were $100 \mathrm{mg} \mathrm{L}^{-1}$ of AMX and $100 \mathrm{mg} \mathrm{L}^{-1}$ of AMP. Current density: $30 \mathrm{~mA} \mathrm{~cm}^{-2}$. UV light: $254 \mathrm{~nm}$.

More remarkable differences are observed when the results obtained in sulphate and chlorine media are compared, indicating that the oxidation pathways involved in each case should be different. The electrolysis and photoelectrolysis in chlorine media show a very different profile, with three clear regions of oxidation. Initially, a fast mineralization occurs, then the kinetic becomes slower, and at the end of the treatment it increases abruptly. Initially, antibiotics are the majority of pollutants. As was observed in Figure 3, they rapidly react with active chlorine species, leading to the formation of chlorinated intermediates [44]. Additionally, the decrease of TOC concentration seems to indicate that the depletion of any organic may occur-most likely, carboxylic or methyl groups present in the antibiotic molecule and split up in the first stages. These short-chain organics can be further oxidized to carbon dioxide, justifying the mineralization in this first zone. Additionally, the depletion of the initial compound leads also to the appearance of a large amount of chlorinated aromatic intermediates [12], whose reactivity differs from the initial AMX and AMP (chlorinated compounds generally show higher stability to oxidation) and whose further oxidation can lead to both chlorinated and non-chlorinated aliphatic intermediates, and not directly to carbon dioxide. This different reactivity can explain the change observed in the kinetics in the second zone. After that, the rapid and efficient mineralization of short-chain organics may explain the fast kinetic observed in the third zone.

The different profiles observed in sulphate and chlorine media can be related to the oxidants formed in each case, and to the extent of the oxidation reaction from close proximity to the electrode surface to the bulk. In both cases, ozone (Equation (3)) and hydrogen peroxide (Equation (4)) can be formed. Thus, the differences may be related mainly to the different reactivity of persulfate (Equation (1)) and hypochlorite (Equation (7)).

Following this, the effect of ultrasound (US) irradiation on electrolysis was evaluated. As is known [45-49], US irradiation produces a cavitation phenomenon. This releases a large amount of energy that promotes the generation of radicals [32] and the formation of activated oxidant species (Equations (10-13)). Additionally, by coupling sonolysis and electrolysis, the transfer of pollutant from the bulk to the closer to the electrode surface can also be favored.

$$
\begin{gathered}
\mathrm{H}_{2} \mathrm{O}+\text { US wave } \rightarrow \mathrm{H}^{\bullet}+{ }^{\bullet} \mathrm{OH} \\
\mathrm{S}_{2} \mathrm{O}_{8}{ }^{-2}+\text { US wave } \rightarrow 2\left(\mathrm{SO}_{4}^{-}\right)^{\bullet} \\
\mathrm{S}_{2} \mathrm{O}_{8}{ }^{-2}+{ }^{\bullet} \mathrm{OH} \rightarrow 2 \mathrm{HSO}_{4}{ }^{-}+\left(\mathrm{SO}_{4}{ }^{-}\right)^{\bullet}+\frac{1}{2} \mathrm{O}_{2} \\
\mathrm{~S}_{2} \mathrm{O}_{8}{ }^{-2}+{ }^{\bullet} \mathrm{H} \rightarrow \mathrm{HSO}_{4}{ }^{-}+\left(\mathrm{SO}_{4}{ }^{-}\right)^{\bullet}
\end{gathered}
$$


Figure 5 shows TOC removal in the semi-log scale of the combined process of sonoelectrolysis, together with the results of the single processes of electrolysis and sonolysis. Two acoustic frequencies were studied: $20 \mathrm{kHz}$ (low-frequency ultrasound) and $10 \mathrm{MHz}$ (high-frequency ultrasound). As expected, sonolysis at both frequencies shows no mineralization. However, when it is coupled to electrolysis, a slight improvement is observed during the first stages of the process, mainly in the case of low-frequency US. Thus, the trend changes and kinetics of electrolysis are higher than those of the combined processes. At low frequencies, ultrasound promotes the violent collapse of bubbles and, consequently, a large amount of radicals is produced, favoring the activation of oxidants. This is not observed at high frequencies [50], where the activation of persulfate is not promoted and an inhibition of its oxidative power is observed.

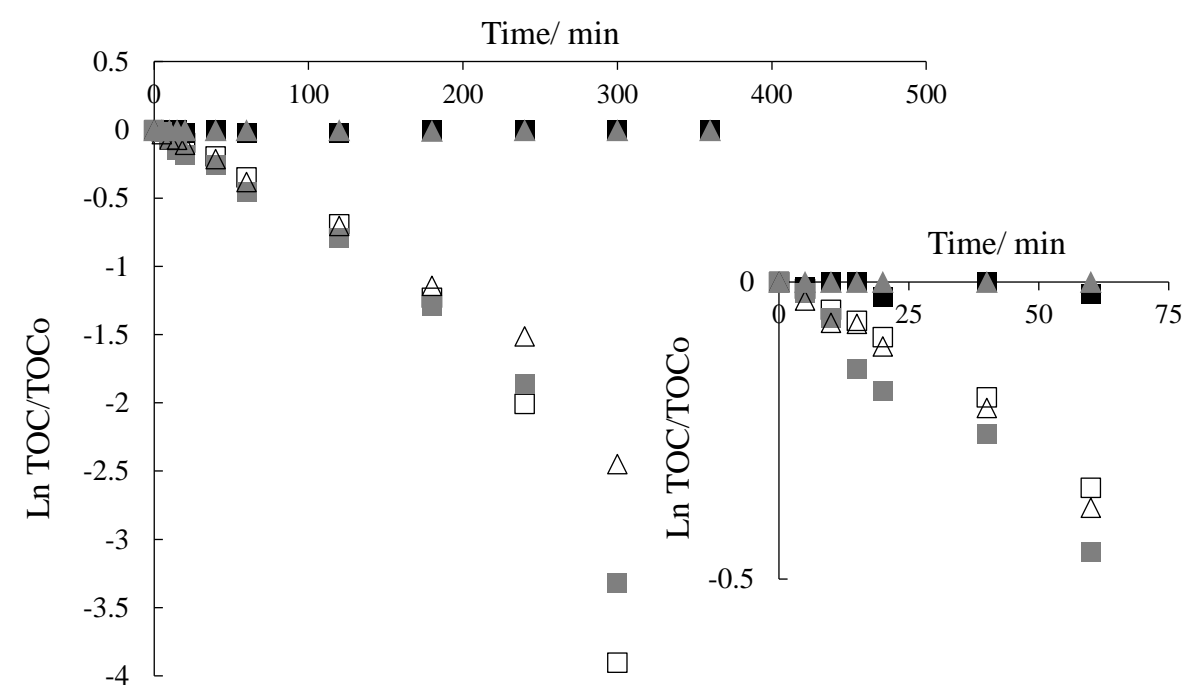

Figure 5. TOC removal in the semi-log scale during the electrolysis ( $\square$ ), sonoelectrolysis at $20 \mathrm{kHz}(\square)$, sonoelectrolysis at $10 \mathrm{MHz}(\Delta)$ and sonolysis at $20 \mathrm{kHz}(\mathbf{\square})$ sonolysis at $10 \mathrm{MHz}(\Delta)$ of AMX and AMP solutions carried out in sulphate media (square symbols, $3 \mathrm{~g} \mathrm{~L}^{-1}$ of $\mathrm{Na}_{2} \mathrm{SO}_{4}$ ). Initial concentration: $100 \mathrm{mg} \mathrm{L}^{-1}$ of AMX and $100 \mathrm{mg} \mathrm{L}^{-1}$ of AMP. Current density: $30 \mathrm{~mA} \mathrm{~cm}^{-2}$.

In light of the obtained results, it can be said that although irradiation by UV light or US generates $\mathrm{SO}_{4} \bullet$ and $\mathrm{Cl}^{\bullet}$ species, and also promotes the formation of $\bullet \mathrm{OH}$, this is not reflected in an improvement of the degradation process. Therefore, the small effect observed in this study may be indicative of the existence of other non-irradiated activation processes. In this way, the interaction between the oxidants (including ozone, hydrogen peroxide and oxidant formed from the oxidation of the supporting electrolyte) that coexist in a region close to the electrode surface may be the main factor responsible for the typically high efficiencies of conductive diamond electrolysis.

In order to clarify this point, Figure 6 compares the synergistic effect (estimated according to Equation (14)) of the electro-irradiated treatment of AMX and AMP solutions and of other compounds previously studied in the literature [32,51] under similar operation conditions.

$$
S I=\frac{k_{\text {electro-irradiated process }}}{k_{\text {electrolysis }}+k_{\text {irradiated process }}}
$$




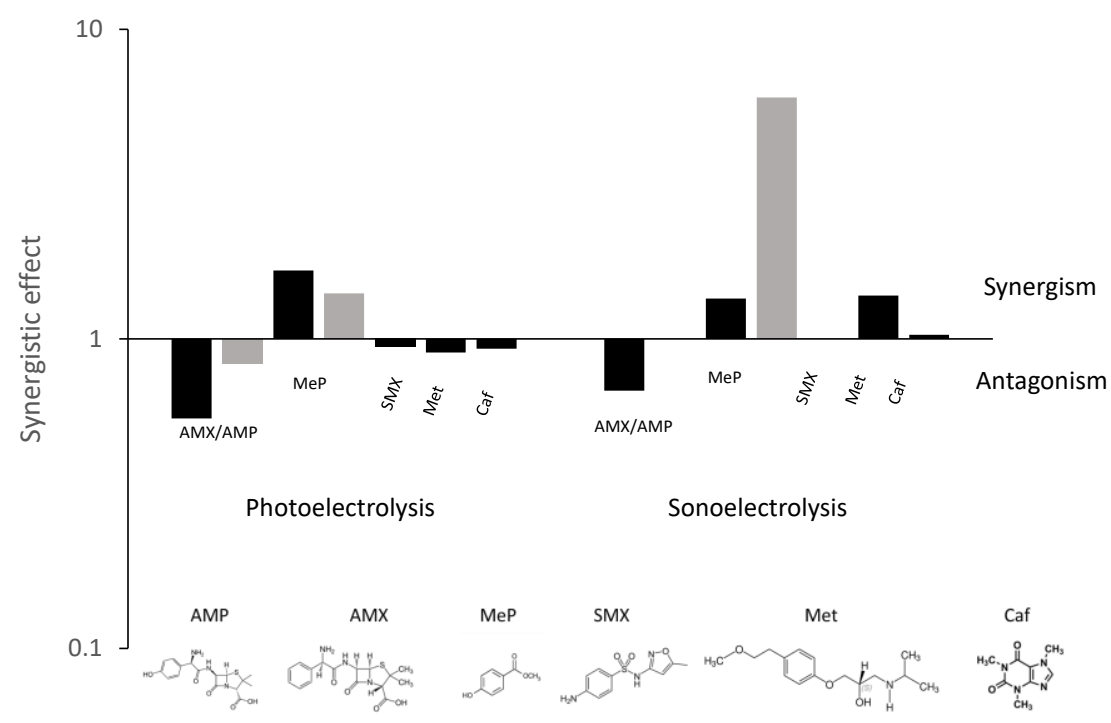

Figure 6. Synergistic/antagonistic effect of coupling irradiation techniques (UV light or ultrasound (US)) to the electrolysis of different organics: a mixture of amoxicillin and ampicillin (AMX/AMP), methylparaben (MeP), sulfomethoxazole (SMX), metroprolol (Met) and caffeine (Caf). Supporting electrolyte: $(\square)$ sulphate and $(\square)$ chlorine.

As can be observed, the effect depends on the nature of the organic and supporting media. As reported before, the irradiation of US and/or UV during the electrolysis process leads to an excessive formation of radicals, which can recombine, forming less powerful and more stable oxidants, or can decompose to oxygen (Equations (15-18)). This means that these reactions may compete with organic oxidation and that active radicals are not available to oxidize organics. Thus, irradiation may cause an antagonistic effect on the degradation process.

$$
\begin{gathered}
2 \bullet \mathrm{OH} \rightarrow \mathrm{H}_{2} \mathrm{O}_{2} \\
\bullet \mathrm{OH}+\left(\mathrm{SO}_{4}{ }^{-}\right)^{\bullet} \rightarrow \mathrm{HSO}_{5}{ }^{-} \\
\mathrm{HSO}_{5}{ }^{-} \rightarrow \mathrm{HSO}_{4}{ }^{-}+0.5 \mathrm{O}_{2} \\
\mathrm{HSO}_{4}{ }^{-}+{ }^{\bullet} \mathrm{OH} \rightarrow \mathrm{SO}_{4}{ }^{2-}+\mathrm{H}_{2} \mathrm{O}
\end{gathered}
$$

This negative effect is not observed in all cases and cannot be explained by attending to mass transfer limitations; however, it may indicate the important role of chemical reactivity on the organic molecules. Thus, the synergism or antagonism of coupling irradiation techniques to electrochemical oxidation is difficult to predict at present. Nevertheless, these results shed light on the importance of the cocktail of oxidants that coexist in close proximity to the electrode surface during conductive diamond electrolysis, which may explain the typically high efficiencies of conductive diamond electrolysis.

\section{Materials and Methods}

\subsection{Chemicals}

All chemicals were of analytical grade and used as received. Anhydrous sodium sulphate and sodium chloride were purchased from Fluka (Bucharest, Romania), and amoxicillin (90\% purity), ampicillin (96\% purity) and acetonitrile (HPLCE grade) were purchased from Sigma-Aldrich (St. Louis, MO, USA), and sulphuric acid and hydrochloric acid were purchased from Merck (Darmstadt, Germany). Solutions were prepared using double deionized water (Millipore Milli-Q system, Merck Millipore, Madrid, Spain). 


\subsection{Electrochemical Cell}

The electrolytic essays were carried out in a single-compartment electrochemical flow cell. Synthetic wastewater contain the electrolyte $\left(3 \mathrm{~g} \mathrm{~L}^{-1}\right.$ of $\mathrm{Na}_{2} \mathrm{SO}_{4}$ or $3.7 \mathrm{~g} \mathrm{~L}^{-1}$ of $\left.\mathrm{NaCl}\right)$ and antibiotics (100 $\mathrm{mg} \mathrm{dm}^{-3}$ of each). Details of the cell and of the auxiliary equipment can be found elsewhere [52]. Irradiated experiments were carried out using the same fluid-dynamic conditions as the electrolysis setup. For irradiated-electrolysis tests, the UV lamp (Vilber Lourmat filtered lamp, VL-215.MC, with a power of $4 \mathrm{~W}$, Vilber, Marne, France) or the ultrasound (acoustic frequency: $20 \mathrm{kHz}$ (UP200S, Hielscher Ultrasonics GmbH, Hielscher, Berlin, Germany) and $10 \mathrm{MHz}$ (EPOCH 650, Olympus, Barcelona, Spain) were immersed in the reservoir tank.

\subsection{Analysis Procedures}

The concentration of antibiotics and the mineralization of the solutions were monitored by liquid chromatography at $220 \mathrm{~nm}$ wavelength (HPLC, Agilent1260 series, Agilent, Madrid, Spain) and total organic carbon (TOC, Multi N/C 3100 Analytik Jena analyser, Analytik Jena AG, Jena, Germany) analysis, respectively. For the chromatographic analysis the column used was an Elipse Plus $35 \mu \mathrm{m} \mathrm{C18}$, a mixture of acetonitrile (A) and water with phosphoric acid ( $\mathrm{pH} 2)$ was used as a mobile phase, the volume injection was set to $20 \mu \mathrm{L}$, and the temperature was fixed at $35^{\circ} \mathrm{C}$. Before analysis, all samples were filtered using $0.45 \mu \mathrm{m}$ nylon filters. The concentration of inorganic species was determined by titration or by ion chromatography (IC, Shimadzu LC-20A (Shimadzu, Duisburg, Germany). The IC chromatograph was equipped with a ShodexIC I-524A column; mobile phase, $2.5 \mathrm{mM}$ phthalic acid at $\mathrm{pH} 4.0$; flow rate, $1 \times 10^{-3} \mathrm{dm}^{3} \mathrm{~min}^{-1}$. Hypochlorite $\left(\mathrm{HClO}^{-}\right)$ was determined by titration with $0.001 \mathrm{~mol} \mathrm{~L}^{-1} \mathrm{As}_{2} \mathrm{O}_{3}$ in $2.0 \mathrm{~mol} \mathrm{~L}^{-1} \mathrm{NaOH}$. Peroxosulfate was quantified iodometrically

\section{Conclusions}

The following conclusions have been drawn:

- The conductive diamond electrolysis is able to attain the complete mineralization of amoxicillin and ampicillin solutions. The removal efficiency depends on the current density and supporting media, with the antibiotic degradation rate and mineralization favored in the presence of chloride.

- The mineralization rate of AMX and AMP solutions during electrolysis, photoelectrolysis and sonoelectrolysis fits well to pseudo-first order kinetics, although two or three reaction zones are distinguished in sulphate and chloride media, respectively. This may indicate the existence of complex mechanisms in which indirect oxidation is very important.

- The effect of irradiating UV light and/or US waves during the electrolysis of AMX and AMP is not very relevant. This may be explained in terms of the high contribution of mediated oxidation in the single electrolysis process or of the massive formation of radicals during electro-irradiated processes, which recombine to form stable oxidants.

Author Contributions: Investigation, F.L.S.; Methodology, F.L.S., C.S. and M.A.R.; Project administration, M.R.V.L., P.C. and M.A.R.; Supervision, M.R.V.L., P.C. and M.A.R.; Writing-original draft, F.L.S., C.S. and M.A.R.

Funding: Financial support from the Regional Government of Castilla-La Mancha (Spain) and European Union (EU, FEDER) through project SBPLY/17/180501/000396 are gratefully acknowledged. CNPq (grants 301492/2013-1 and 465571/2014-0 (INCT-DATREM)) and Capes and São Paulo Research Foundation (FAPESP) (grants \#2016/01937-4, \#2014/50945-4, \#2013/16690-6, \#2016/11672-8 and \#2017/10118-0) are also acknowledge.

Conflicts of Interest: The authors declare no conflict of interest. 


\section{References}

1. Feng, L.; van Hullebusch, E.D.; Rodrigo, M.A.; Esposito, G.; Oturan, M.A. Removal of residual anti-inflammatory and analgesic pharmaceuticals from aqueous systems by electrochemical advanced oxidation processes. A review. Chem. Eng. J. 2013, 228, 944-964. [CrossRef]

2. Rodrigo, M.A.; Oturan, N.; Oturan, M.A. Electrochemically Assisted Remediation of Pesticides in Soils and Water: A Review. Chem. Rev. 2014, 114, 8720-8745. [CrossRef] [PubMed]

3. Vieno, N.; Tuhkanen, T.; Kronberg, L. Elimination of pharmaceuticals in sewage treatment plants in Finland. Water Res. 2007, 41, 1001-1012. [CrossRef] [PubMed]

4. Radjenovic, J.; Jelic, A.; Petrovic, M.; Barcelo, D. Determination of pharmaceuticals in sewage sludge by pressurized liquid extraction (PLE) coupled to liquid chromatography-tandem mass spectrometry (LC-MS/MS). Anal. Bioanal. Chem. 2009, 393, 1685-1695. [CrossRef] [PubMed]

5. Klavarioti, M.; Mantzavinos, D.; Kassinos, D. Removal of residual pharmaceuticals from aqueous systems by advanced oxidation processes. Environ. Int. 2009, 35, 402-417. [CrossRef] [PubMed]

6. Urtiaga, A.M.; Perez, G.; Ibanez, R.; Ortiz, I. Removal of pharmaceuticals from a WWTP secondary effluent by ultrafiltration/reverse osmosis followed by electrochemical oxidation of the RO concentrate. Desalination 2013, 331, 26-34. [CrossRef]

7. Liu, X.; Lu, S.; Guo, W.; Xi, B.; Wang, W. Antibiotics in the aquatic environments: A review of lakes, China. Sci. Total Environ. 2018, 627, 1195-1208. [CrossRef]

8. Carvalho, I.T.; Santos, L. Antibiotics in the aquatic environments: A review of the European scenario. Environ. Int. 2016, 94, 736-757. [CrossRef]

9. Al Aukidy, M.; Verlicchi, P.; Voulvoulis, N. A framework for the assessment of the environmental risk posed by pharmaceuticals originating from hospital effluents. Sci. Total Environ. 2014, 493, 54-64. [CrossRef]

10. Dewil, R.; Mantzavinos, D.; Poulios, I.; Rodrigo, M.A. New perspectives for Advanced Oxidation Processes. J. Environ. Manag. 2017, 195, 93-99. [CrossRef]

11. Sires, I.; Brillas, E.; Oturan, M.A.; Rodrigo, M.A.; Panizza, M. Electrochemical advanced oxidation processes: Today and tomorrow. A review. Environ. Sci. Pollut. Res. 2014, 21, 8336-8367. [CrossRef] [PubMed]

12. Martinez-Huitle, C.A.; Rodrigo, M.A.; Sires, I.; Scialdone, O. Single and Coupled Electrochemical Processes and Reactors for the Abatement of Organic Water Pollutants: A Critical Review. Chem. Rev. 2015, 115, 13362-13407. [CrossRef] [PubMed]

13. Brillas, E. Electro-Fenton, UVA Photoelectro-Fenton and Solar Photoelectro-Fenton Treatments of Organics in Waters Using a Boron-Doped Diamond Anode: A Review. J. Mex. Chem. Soc. 2014, 58, 239-255. [CrossRef]

14. Brillas, E.; Martínez-Huitle, C.A. Decontamination of wastewaters containing synthetic organic dyes by electrochemical methods. An updated review. Appl. Catal. B Environ. 2015, 166-167, 603-643. [CrossRef]

15. Martinez-Huitle, C.A.; Brillas, E. Decontamination of wastewaters containing synthetic organic dyes by electrochemical methods: A general review. Appl. Catal. B Environ. 2009, 87, 105-145. [CrossRef]

16. Sires, I.; Brillas, E. Remediation of water pollution caused by pharmaceutical residues based on electrochemical separation and degradation technologies: A review. Environ. Int. 2012, 40, $212-229$. [CrossRef] [PubMed]

17. Canizares, P.; Saez, C.; Sanchez-Carretero, A.; Rodrigo, M.A. Synthesis of novel oxidants by electrochemical technology. J. Appl. Electrochem. 2009, 39, 2143-2149. [CrossRef]

18. De Araujo, D.M.; Cotillas, S.; Saez, C.; Canizares, P.; Martinez-Huitle, C.A.; Andres Rodrigo, M. Activation by light irradiation of oxidants electrochemically generated during Rhodamine B elimination. J. Electroanal. Chem. 2015, 757, 144-149. [CrossRef]

19. Yoon, Y.; Cho, E.; Jung, Y.; Kwon, M.; Yoon, J.; Kang, J.-W. Evaluation of the formation of oxidants and by-products using $\mathrm{Pt} / \mathrm{Ti}, \mathrm{RuO} 2 / \mathrm{Ti}$, and IrO2/Ti electrodes in the electrochemical process. Environ. Technol. 2015, 36, 317-326. [CrossRef] [PubMed]

20. Dirany, A.; Sires, I.; Oturan, N.; Oturan, M.A. Electrochemical abatement of the antibiotic sulfamethoxazole from water. Chemosphere 2010, 81, 594-602. [CrossRef] [PubMed]

21. Garcia-Segura, S.; Cavalcanti, E.B.; Brillas, E. Mineralization of the antibiotic chloramphenicol by solar photoelectro-Fenton. From stirred tank reactor to solar pre-pilot plant. Appl. Catal. B Environ. 2014, 144, 588-598. [CrossRef] 
22. Haidar, M.; Dirany, A.; Sires, I.; Oturan, N.; Oturan, M.A. Electrochemical degradation of the antibiotic sulfachloropyridazine by hydroxyl radicals generated at a BDD anode. Chemosphere 2013, 91, 1304-1309. [CrossRef] [PubMed]

23. Ji, Y.; Fan, Y.; Liu, K.; Kong, D.; Lu, J. Thermo activated persulfate oxidation of antibiotic sulfamethoxazole and structurally related compounds. Water Res. 2015, 87, 1-9. [CrossRef] [PubMed]

24. Wu, J.; Zhang, H.; Oturan, N.; Wang, Y.; Chen, L.; Oturan, M.A. Application of response surface methodology to the removal of the antibiotic tetracycline by electrochemical process using carbon-felt cathode and DSA (Ti/RuO2-IrO2) anode. Chemosphere 2012, 87, 614-620. [CrossRef] [PubMed]

25. Xiao, S.; Song, Y.; Tian, Z.; Tu, X.; Hu, X.; Liu, R. Enhanced mineralization of antibiotic berberine by the photoelectrochemical process in presence of chlorides and its optimization by response surface methodology. Environ. Earth Sci. 2015, 73, 4947-4955. [CrossRef]

26. Cotillas, S.; Lacasa, E.; Saez, C.; Canizares, P.; Rodrigo, M.A. Electrolytic and electro-irradiated technologies for the removal of chloramphenicol in synthetic urine with diamond anodes. Water Res. 2018, 128, 383-392. [CrossRef]

27. Cotillas, S.; Lacasa, E.; Saez, C.; Canizares, P.; Rodrigo, M.A. Removal of pharmaceuticals from the urine of polymedicated patients: A first approach. Chem. Eng. J. 2018, 331, 606-614. [CrossRef]

28. Stackelberg, P.E.; Furlong, E.T.; Meyer, M.T.; Zaugg, S.D.; Henderson, A.K.; Reissman, D.B. Persistence of pharmaceutical compounds and other organic wastewater contaminants in a conventional drinking-watertreatment plant. Sci. Total Environ. 2004, 329, 99-113. [CrossRef] [PubMed]

29. Dominguez, J.R.; Gonzalez, T.; Palo, P.; Sanchez-Martin, J.; Rodrigo, M.A.; Saez, C. Electrochemical Degradation of a Real Pharmaceutical Effluent. Water Air Soil Pollut. 2012, 223, 2685-2694. [CrossRef]

30. Sopaj, F.; Rodrigo, M.A.; Oturan, N.; Podvorica, F.I.; Pinson, J.; Oturan, M.A. Influence of the anode materials on the electrochemical oxidation efficiency. Application to oxidative degradation of the pharmaceutical amoxicillin. Chem. Eng. J. 2015, 262, 286-294. [CrossRef]

31. Perez, J.F.; Llanos, J.; Saez, C.; Lopez, C.; Canizares, P.; Rodrigo, M.A. Treatment of real effluents from the pharmaceutical industry: A comparison between Fenton oxidation and conductive-diamond electro-oxidation. J. Environ. Manag. 2017, 195, 216-223. [CrossRef] [PubMed]

32. Dionisio, D.; Motheo, A.J.; Sáez, C.; Rodrigo, M.A. Effect of the electrolyte on the electrolysis and photoelectrolysis of synthetic methyl paraben polluted wastewater. Sep. Purif. Technol. 2019, 208, 201-207. [CrossRef]

33. Serrano, K.; Michaud, P.A.; Comninellis, C.; Savall, A. Electrochemical preparation of peroxodisulfuric acid using boron doped diamond thin film electrodes. Electrochim. Acta 2002, 48, 431-436. [CrossRef]

34. Cotillas, S.; de Vidales, M.J.M.; Llanos, J.; Saez, C.; Canizares, P.; Rodrigo, M.A. Electrolytic and electro-irradiated processes with diamond anodes for the oxidation of persistent pollutants and disinfection of urban treated wastewater. J. Hazard. Mater. 2016, 319, 93-101. [CrossRef] [PubMed]

35. Martin de Vidales, M.J.; Cotillas, S.; Perez-Serrano, J.F.; Llanos, J.; Saez, C.; Canizares, P.; Rodrigo, M.A. Scale-up of electrolytic and photoelectrolytic processes for water reclaiming: A preliminary study. Environ. Sci. Pollut. Res. Int. 2016, 23, 19713-19722. [CrossRef] [PubMed]

36. Boye, B.; Dieng, M.M.; Brillas, E. Electrochemical degradation of 2,4,5-trichlorophenoxyacetic acid in aqueous medium by peroxi-coagulation. Effect of $\mathrm{pH}$ and UV light. Electrochim. Acta 2003, 48, 781-790. [CrossRef]

37. Diagne, M.; Oturan, N.; Oturan, M.A.; Sires, I. UV-C light-enhanced photo-Fenton oxidation of methyl parathion. Environ. Chem. Lett. 2009, 7, 261-265. [CrossRef]

38. Shih, Y.J.; Chen, K.H.; Huang, Y.H. Mineralization of organic acids by the photo-electrochemical process in the presence of chloride ions. J. Taiwan Inst. Chem. Eng. 2014, 45, 962-966. [CrossRef]

39. Matafonova, G.; Batoev, V. Recent advances in application of UV light-emitting diodes for degrading organic pollutants in water through advanced oxidation processes: A review. Water Res. 2018, 132, 177-189. [CrossRef]

40. Souza, F.L.; Sáez, C.; Cañizares, P.; Motheo, A.J.; Rodrigo, M.A. Coupling photo and sono technologies to improve efficiencies in conductive diamond electrochemical oxidation. Appl. Catal. B Environ. 2013, 144, 121-128. [CrossRef]

41. Rubi-Juarez, H.; Cotillas, S.; Saez, C.; Canizares, P.; Barrera-Diaz, C.; Rodrigo, M.A. Use of conductive diamond photo-electrochemical oxidation for the removal of pesticide glyphosate. Sep. Purif. Technol. 2016, 167, 127-135. [CrossRef] 
42. Aquino, J.M.; Miwa, D.W.; Rodrigo, M.A.; Motheo, A.J. Treatment of actual effluents produced in the manufacturing of atrazine by a photo-electrolytic process. Chemosphere 2017, 172, 185-192. [CrossRef] [PubMed]

43. Vieira dos Santos, E.; Saez, C.; Canizares, P.; Rodrigo, M.A.; Martinez-Huitle, C.A. Coupling Photo and Sono Technologies with BDD Anodic Oxidation for Treating Soil-Washing Effluent Polluted with Atrazine. J. Electrochem. Soc. 2018, 165, E262-E267. [CrossRef]

44. Comninellis, C.; Nerini, A. Anodic-oxidation of phenol in the presence of nacl for waste-water treatment. J. Appl. Electrochem. 1995, 25, 23-28. [CrossRef]

45. Garbellini, G.S.; Salazar-Banda, G.R.; Avaca, L.A. Effects of ultrasound on the degradation of pentachlorophenol by Boron-Doped diamond electrodes. Port. Electrochim. Acta 2010, 28, 405-415. [CrossRef]

46. Ma, Y.S.; Sung, C.F.; Lin, J.G. Degradation of carbofuran in aqueous solution by ultrasound and Fenton processes: Effect of system parameters and kinetic study. J. Hazard. Mater. 2010, 178, 320-325. [CrossRef] [PubMed]

47. Bringas, E.; Saiz, J.; Ortiz, I. Kinetics of ultrasound-enhanced electrochemical oxidation of diuron on boron-doped diamond electrodes. Chem. Eng. J. 2011, 172, 1016-1022. [CrossRef]

48. Rooze, J.; Rebrov, E.V.; Schouten, J.C.; Keurentjes, J.T.F. Effect of resonance frequency, power input, and saturation gas type on the oxidation efficiency of an ultrasound horn. Ultrason. Sonochem. 2011, 18, 209-215. [CrossRef]

49. Martin de Vidales, M.J.; Barba, S.; Saez, C.; Canizares, P.; Rodrigo, M.A. Coupling ultraviolet light and ultrasound irradiation with Conductive-Diamond Electrochemical Oxidation for the removal of progesterone. Electrochim. Acta 2014, 140, 20-26. [CrossRef]

50. Steter, J.R.; Dionisio, D.; Lanza, M.R.V.; Motheo, A.J. Electrochemical and sonoelectrochemical processes applied to the degradation of the endocrine disruptor methyl paraben. J. Appl. Electrochem. 2014, 44, 1317-1325. [CrossRef]

51. Martin de Vidales, M.J.; Saez, C.; Perez, J.F.; Cotillas, S.; Llanos, J.; Canizares, P.; Rodrigo, M.A. Irradiation-assisted electrochemical processes for the removal of persistent organic pollutants from wastewater. J. Appl. Electrochem. 2015, 45, 799-808. [CrossRef]

52. Cotillas, S.; Lacasa, E.; Saez, C.; Canizares, P.; Rodrigo, M.A. Disinfection of urine by conductive-diamond electrochemical oxidation. Appl. Catal. B Environ. 2018, 229, 63-70. [CrossRef] 